\title{
EXPLOITATION IS A PREREQUISITE FOR CONSERVATION OF ASTACUS ASTACUS
}

\author{
T. TAUGBøL
}

Norwegian Institute for Nature Research, Fakkelgaarden, N-2624 Lillehammer, Norway E-Mail: trond.taugbol@nina.no

Reçu le 6 janvier 2004

Received January 6, 2004

Accepté le 6 juillet 2004

Accepted July 6, 2004

\begin{abstract}
The noble crayfish, Astacus astacus, is highly valued from a recreational and economical point of view. In most noble crayfish areas, there are long traditions of crayfish catching. The noble crayfish is also included in national and international Red Lists as a vulnerable or threatened species. Intuitively, the first thought is that such a species should be protected from exploitation. However, in many cases the possibility for exploitation and local economic benefits may be important for the conservation of the species. For the noble crayfish this is especially true. The greatest threat against noble crayfish is the man-facilitated spread of plague-carrying alien crayfish species. If local people are allowed and encouraged to catch and make a benefit from noble crayfish, this is also the best protection against illegal stocking of alien crayfish. The possibility to exploit the crayfish is of major importance for the will to protect. Examples from Norway showing different ways of getting an economical and recreational outcome from the noble crayfish are presented.
\end{abstract}

Key-words: Astacus astacus, noble crayfish, exploitation, conservation, red-listed species, socioeconomics.

\section{L'EXPLOITATION EN TANT QUE PREREQUIS POUR LA CONSERVATION D'ASTACUS ASTACUS}

\section{RÉSUMÉ}

L'écrevisse noble, Astacus astacus, a une grande valeur d'un point de vue festif et économique. Dans la plupart des régions où vit l'écrevisse noble il y a une longue tradition de pêche d'écrevisses. L'écrevisse noble est aussi incluse dans les Listes Rouges nationale et internationale des espèces en danger. Intuitivement, la première pensée est que cette espèce doit être protégée de l'exploitation. Cependant, dans beaucoup de cas la possibilité d'exploiter cette espèce et les avantages économiques locaux peuvent être importants pour sa conservation. Ceci est particulièrement vrai pour l'écrevisse noble. La plus grande menace sur l'écrevisse noble est l'homme qui peut faciliter la propagation des écrevisses étrangères porteuses de la peste. Que les populations locales soient autorisées et encouragées à pêcher et à faire des bénéfices avec l'écrevisse noble, est aussi la meilleure protection contre la réintroduction illégale des écrevisses étrangères. La possibilité d'exploiter les écrevisses est d'une importance majeure pour la protection. Des 
exemples norvégiens montrant différentes manières d'obtenir des résultats économiques et récréatifs avec l'écrevisse noble sont présentés.

Mots-clés : Astacus astacus, écrevisse noble, exploitation, conservation, espèces de la liste rouge, socioéconomie.

\section{INTRODUCTION}

Noble crayfish, Astacus astacus, is recognised as a threatened species. It is classified as a declining, care demanding species (DC) in the Norwegian Red List (DIRECTORATE FOR NATURE MANAGEMENT 1999) and as vulnerable (VU) in the international Red List of threatened species (IUCN 1998), and also included in the Bern-convention and in the EU Habitat Directive. On the other hand, the noble crayfish is also highly valued from a recreational and economical point of view. In most noble crayfish areas, there are long traditions of crayfish catching and eating although in many countries these habits have become extinct (SWAHN, 2004), mostly due to the severe decline in crayfish abundance. In Scandinavia, however, the ritual and ceremonial form of social intercourse called the "The Crayfish Party", developed in Sweden during the second half of the nineteenth century, is still an extremely popular late-summer tradition. The noble crayfish as the common name indicates, has a reputation as the most tasty and exclusive crayfish species and thus fetches a high market price. First hand value in Norway in 2003 was 300-350 NOK per kg (approx. 40 Euros).

The Red List of threatened species has inevitably become linked to several decision-making processes, for instance to constrain the exploitation of the species (POSSINGHAM et al., 2002). The hypothesis of attaching and realising market values as a mean of conservation of biodiversity has, however, gained ground over the last decade (SHACKLETON, 2001). In some areas, ecotourism providing local economic benefits has shown to be effective as a component of a conservation strategy (STEM et al., 2003). In many cases the possibility for exploitation may be important for the conservation of the species, and for the noble crayfish this is especially true. However, due to the status as a red-listed species, a common attitude among conservationists and environmental protection officers who are not familiar with the sociocultural aspects of crayfish utilization and the pattern of threats is that such a species should be protected from exploitation.

\section{EXPLOITATION AS A PROTECTIVE EFFORT}

Conservation strategy and actions must relate to the threats, and the sociocultural aspect is imperative to have in mind when discussing and implementing management and conservation strategies. The greatest threat against the noble crayfish is the manfacilitated spread of plague-carrying alien crayfish, and efforts to prevent further spreading must include many different actions (TAUGB $\varnothing \mathrm{L}$ and SKURDAL 1999). Adequate legislation is a necessary basis for further actions. A unified goal and good cooperation/coordination between neighbouring countries and regions, and between different authority levels are likewise important. Of even greater importance is, in my opinion, the possibility for exploitation and economical and recreational benefits. Exploitation as a protective effort may sound like a contradiction, but I claim it is a prerequisite for counteracting illegal stocking of alien crayfish. In most areas with noble crayfish populations (in past or present times) there are or have been traditions of crayfish catching. If local people are allowed and encouraged to catch and benefit from the noble crayfish, and are convinced that the noble crayfish is the "best" species, they are also eager to protect it. With alien crayfish 
easily accessible, as they are in most parts of Europe, it is impossible to prevent local people from stocking them if they want, i.e. are convinced that they benefit more from the alien crayfish.

\section{KNOWLEDGE AND ATTITUDE A KEY FACTOR}

Knowledge and attitude of local people is a key factor to prevent the spreading of alien crayfish. "Shaping" the attitude requires actions from the authorities. Information is of crucial importance. Such information should highlight the advantages of the noble crayfish (most tasty and exclusive, fetches the highest price, the traditional species, etc.) and provide good arguments against the introduction of alien species. Arguments that not only relate to biological diversity and illegality of introductions (such arguments often have minor effect), but that also directly relate to the recreational and economical value of the waters. From Sweden it is known that an increasing number of signal crayfish populations develop into stunted populations (L. Edsman, pers. comm.). The crayfish are too small to have a commercial or recreational value and also cause problems for the gillnet fishery because the crayfish eat the fish. Although the "scientifically correct nature" or generality of these observations are unknown, I see no problem of using this objection as a supporting argument against the spreading of alien crayfish.

State financial support for restocking/restoring noble crayfish populations, and promoting the sustainable use of the crayfish resource are other actions favouring the will to protect. To prevent illegal stocking of signal crayfish in Norway after crayfish plague outbreaks in two watercourses in 1987 and 1998, the authorities immediately kept focus on reintroduction of the noble crayfish in collaboration and the costs shared with the landowners association (TAUGBØL et al., 1993; TAUGBØL, 2004). The prospect of exploitation was the driving force for the landowners. In 2002, signal crayfish was found in a border lake between Norway. The signal crayfish cannot spread by natural migration, and it is more important than ever that local people desire noble crayfish and want to benefit from them and that they do not want the signal crayfish. As a precautionary action, to further reduce the risk for illegal stocking, a general ban on the catching of signal crayfish in Norway should be adopted and communicated to fishermen and landowners. If there will be no legal opportunity for catching signal crayfish, those planning a possible illegal stocking may then reconsider.

\section{ECONOMICAL OUTCOME FROM CRAYFISH}

As already stressed, exploitation and conservation of noble crayfish are closely linked. Local recreational and economic benefits are important for the will to protect. Below I present five examples from Norway showing different ways of getting economical outcome from the noble crayfish. Such activities have a potential to be further expanded in Norway.

\section{Catching crayfish in Lake Einavann: a considerable additional income for the landowners}

Crayfish was stocked in L. Einavann (area: $13,5 \mathrm{~km}^{2}$, shoreline: $40 \mathrm{~km}$ ) in the late 1950 's and since then a very good population has developed. The catching of crayfish for sale started slowly in the late 1980's. The catch increases every year as more and more landowners realize the value of this resource. In Norway the right to catch fish and crayfish belongs to the landowners along the waterbody.

Catching season is from 6:00 pm August 6 to September 15 and minimum size is $95 \mathrm{~mm}$ total length (national regulations). The yield in the best areas exceeds $20 \mathrm{~kg}$ per ha. Along a $2,7 \mathrm{~km}$ shoreline the harvest has varied between 280 and $370 \mathrm{~kg}$ in 1998- 
2002 , corresponding to a first hand value of $85-110.000$ NOK (10.500-13.750 euros). Thus, for landowners possessing a certain length of the shoreline, crayfish catching means a considerable additional income. There is no indication of overfishing; on the contrary, the level of a maximum sustainable yield is probably much higher.

\section{Lake Steinsfjorden: Free crayfish catching for everybody}

Unlike most water bodies in Norway, L. Steinsfjorden $\left(13,9 \mathrm{~km}^{2}\right)$ is public water, i.e. everybody is allowed to catch crayfish during the catching season. This implies that crayfish trapping in L. Steinsfjorden is very intensive (in total: 50-75.000 trapnights) and includes some 250-300 fishermen. In order to avoid overfishing, the catching season is restricted to only 10 days (August 6-16).

Also under these conditions, with a short catching period and strong competition for the crayfish, the economical outcome is considerable for many fishermen. Catches of $30-75 \mathrm{~kg}$, corresponding to a value of 10-25.000 NOK (1.200-3.000 euros) for a ten days effort is not unusual.

\section{Crayfish catching licenses for sale in Lake Harasjøen}

The crayfish catching in L. Harasjøen $\left(1,88 \mathrm{~km}^{2}\right)$ is managed by the local fishermen's association on behalf of local community to which the fishing rights belong. Catching licenses are sold for 150 NOK to fishermen from the local community and 400 NOK to others. Catching effort is restricted to ten traps per license but the license is valid during the whole catching season (August 6-September 15). Some 100-150 licenses are sold annually giving an income of $30-40.000$ NOK (3.600-4.800 euros) to the association. This money is used for monitoring, control and cultivation of fish and crayfish.

Mean catch of the fishermen is $3-5 \mathrm{~kg}$, but catches of $15-20 \mathrm{~kg}$ (representing a value of $4.500-6.000$ NOK to a cost of $150-400 \mathrm{NOK}$ ) are also frequently reported.

\section{Crayfish as a basis in recreation and experience activity products}

Catching crayfish is an exciting activity, crayfish is a highly priced delicacy and the so-called "crayfish party" with singing and drinking is by many considered as the ultimate party. Thus, crayfish has a commercial potential in recreation and experience activities.

In L. Lyseren $\left(7,4 \mathrm{~km}^{2}\right)$ a landowner offers crayfish catching and eating in idyllic surroundings, for company and private events and celebrations. Normally the group arrives at 5 p.m. and the party ends at 3 a.m. A host takes care of the guests all along. The landowner keeps the equipment needed for crayfish catching. The crayfish meal includes 20 crayfish per person and necessary accessories, except drinks. The price for this event is 1.000 NOK (120 euros) per person.

\section{Renting out the right to catch crayfish}

Many persons interested in crayfish catching are not in the possession of fishing rights. Thus, there is a market for landowners to rent out their right to catch crayfish. For landowners who are not very devoted to the actual catching, economical considerations would normally support the decision to rent out or not: how much crayfish can I catch myself, how much time does it take, and how much money can I get for renting out?

In Norwegian lakes there are examples of a renting price of 10.000 NOK (1.200 euros) for a $1 \mathrm{~km}$ shoreline, no other services or equipment included. In some cases, trapping equipment and lodging have been included in the rent. 


\section{CONCLUSION}

With an easy access to alien crayfish suitable for exploitation, it is impossible to prevent spreading of such species if local people with crayfish catching traditions want otherwise. The possibility to utilize the native crayfish for recreational and economical purposes is of major importance for the will to protect and to avoid illegal stocking of alien crayfish. The knowledge and attitude of local people is thus a key factor in this context. Information directed to fishermen and landowners should stress the economical and recreational values of the native crayfish and provide good arguments against the introduction of alien crayfish. The support of the central authorities, and actions in collaboration with landowners and the local society are likewise important when reestablishing extinct native crayfish populations.

\section{REFERENCES}

DIRECTORATE FOR NATURE MANAGEMENT 1999. Nasjonal rødliste for truete arter i Norge 1998. (Norwegian Red List 1998). DN-report 1999-3. (In Norwegian with English summary).

IUCN 1998. IUCN Red list of Threatened Animals. Cambridge.

POSSINGHAM H. P., ANDELMAN S. J., BURGMAN M. A., MEDELLIN R. A., MASTER L. L., KEITH D. A. 2002. Limits to the use of threatened species lists. Trends in Ecology and Evolution, 17, 503-507.

SHACKLETON C. M. 2001. Re-examining local and market-orientated use of wild species for the conservation of biodiversity. Environmental Conservation, 28, 270-278.

STEM C. J., LASSOIE J. P., LEE D. R., DESHLER D.D., SCHELHAS J.W. 2003. Community participation in ecotourism benefits: The link to conservation practices and perspectives. Society and Natural Resources, 16, 387-413.

SWAHN J. Ö., 2004. The Cultural History of Crayfish. Bull. Fr. Pêche Piscic., 372-372, 917.

TAUGBØL T., 2004. Reintroduction of noble crayfish Astacus astacus after crayfish plague in Norway. Bull. Fr. Pêche Piscic., 372-372, 83-96.

TAUGBØL T., SKURDAL J., HÅSTEIN T. 1993. Crayfish plague and management strategies in Norway. Biological Conservation, 63, 75-82.

TAUGBØL T., and SKURDAL J. 1999. The future of native crayfish in Europe - How to make the best of a bad situation? Crustacean Issues, 11, 271-279. 
